\title{
Androgen Receptors in the Diabetic Rat
}

Marta Tesone, R. M. Oliveira-Filho, L. Biella de Souza Valle, J. C. Calvo, J. L. S. Barañao, V. G. Foglia, and E. H. Charreau

Laboratorio de Esteroides, Instituto de Biología y Medicina Experimental, and Departamento de Química Biológica,

Facultad de Ciencias Exactas y Naturales, Universidad de Buenos Aires, Buenos Aires, Argentina

Summary. Male rats rendered diabetic by IV streptozotocin $(65 \mathrm{mg} / \mathrm{kg}$ body weight) were treated with exogenous insulin or testosterone. Charcoal-coated dextran and polyacrylemide gel electrophoresis techniques were employed in studying the characteristics of androgen (R1881) binding to prostate cytosol protein. In comparison with normal (N) rats, the replacement therapy of diabetic (D) animals with insulin $(\mathrm{D}+\mathrm{I})$ or testosterone $(\mathrm{D}+\mathrm{T})$ was able to restore epididymal weight $(\mathrm{N}=0.40 \pm 0.04 \mathrm{~g} ; \mathrm{D}=$ $0.18 \pm 0.02 \mathrm{~g} ; \mathrm{D}+\mathrm{I}=0.42 \pm 0.05 \mathrm{~g} ; \mathrm{D}+\mathrm{T}=0.40$ $\pm 0.06 \mathrm{~g})$ and total prostate weight $(\mathrm{N}=0.24 \pm$ $0.02 \mathrm{~g} ; \mathrm{D}=0.15 \pm 0.02 \mathrm{~g} ; \mathrm{D}+\mathrm{I}=0.24 \pm 0.05 \mathrm{~g}$; $\mathrm{D}+\mathrm{T}=0.35 \pm 0.06 \mathrm{~g}$ ). Testicular endogenous content of testosterone was restored after insulin treatment $(\mathrm{N}=154 \pm 13 \mathrm{ng} /$ testis; $\mathrm{D}=41 \pm 5 \mathrm{ng} /$ testis; $\mathrm{D}+\mathrm{I}=142 \pm 9 \mathrm{ng} /$ testis $)$, and significant improvements of serum testosterone levels were also achieved $(\mathrm{N}=540 \pm 64 \mathrm{ng} / 100 \mathrm{ml} ; \mathrm{D}=238 \pm$ $37 \mathrm{ng} / 100 \mathrm{ml} ; \mathrm{D}+\mathrm{I}=358 \pm 18 \mathrm{ng} / 100 \mathrm{ml})$. Prostate cytosol of streptozotocin-diabetic rats had strongly lowered capacity for ${ }^{3} \mathrm{H}-\mathrm{R} 1881$ binding compared with controls ( 94 and $12 \mathrm{fmol} / \mathrm{mg}$ protein, respectively). Testosterone treatment produced a 3.3-fold improvement of this lowered value, whereas the increment seen with insulin was less (1.5-fold). It is emphasized that some of the improvements caused by insulin replacement therapy in diabetic animals are due to the partial restoration of testosterone secretion. Thus, the combined actions of insulin and testosterone (instead of insulin alone) seem to be of major importance in the maintenance and regulation of accessory sex glands function.

Key words: Androgen receptors, streptozotocindiabetes, rat prostate, cytosol binding sites, R1881.
Sexual and reproductive disturbances have been reported in connection with diabetes [1-3]. Diabetes in the rat is characterized by atrophy of the accessory sex organs [4], paralleled by a clear-cut reduction in the biosynthesis [5, 6] and metabolism [7] of androgens, as well as in the response of target organs to the exogenous replacement therapy with testosterone [8]. In accessory sex glands of diabetic male rats there is a reduced uptake and retention of ${ }^{3} \mathrm{H}$-testosterone [9].

Several authors have demonstrated both in vitro $[10,11]$, and in vivo [12] that insulin per se can stimulate the growth of prostatic lobes through mechanisms which are not dependent upon the presence either of the pituitary or of the adrenal glands. Furthermore, a synergism between insulin and testosterone in the maintenance of growth and secretory activity of cultured prostatic epithelium $[10,11]$ has been reported.

The present paper deals with the influence of the diabetic state, as well as with the possible role of insulin and testosterone, on the content of the cytoplasmic androgen receptor of the rat prostate.

\section{Materials and Methods}

\section{Steroids and Other Reagents}

The following steroids were used: $5 \alpha$-dihydrotestosterone $(17 \beta-$ hydroxy-5a-androstan-3-one) (DHT) and $\left[1,2,4,5,6,7-{ }^{3} \mathrm{H}\right]-$ $5 \alpha$-dihydrotestosterone ( ${ }^{3} \mathrm{H}$-DHT) (S. A. $100 \mathrm{Ci} / \mathrm{mmol}$ ) were purchased respectively from Sigma Chem. Co. (St. Louis, Mo., USA) and New England Nuclear (Boston, Mass., USA); methyltrienolone (17 $\beta$-hydroxy-17 $\alpha$-methyl-4,9,11-estratrien-3-one) (R1881) (Roussel Uclaf): stock solution of $50 \mathrm{pmol} / \mathrm{ml}$ of ${ }^{3} \mathrm{H}$ R1881 (S. A. $58.2 \mathrm{Ci} / \mathrm{mmol}$ ) was prepared in a solution of toluene-methanol $(9: 1, \mathrm{v} / \mathrm{v})$; radioinert R1881 $(10 \mathrm{nmol} / \mathrm{ml})$ was prepared in ethanol. 
Acrylamide was from Serva Feinbiochemica (Heidelberg, West Germany), agarose from Ind. Biol. Française S. A. (Gennevilliers, France), glycerol from Fisher Sci. Co. (Fair Lawn, N. J., USA), streptozotocin (lot No 60140) from Upjohn (Kalamazoo, Mich., USA) and protamine-zinc insulin from Eli Lilly Co. (Buenos Aires, Argentina). For rapid measurements of blood and urine glucose, Test-Tape (Eli Lilly) was used; otherwise, blood glucose was determined using the Glucostat ${ }^{\circledR}$ kit method (Worthington Biochem. Co., N. J., USA).

\section{Animals}

Male Wistar, 60-day old (150-200 g) rats maintained with regular Purina diet and water ad libitum were used. The animals were divided into four different experimental groups of 10 animals each: (1) control: injected with a daily SC injection of pure corn oil $(0.5 \mathrm{ml} / \mathrm{kg}$ body weight) during 2 weeks; (2) diabetic: treated with corn oil in the same schedule as the controls; diabetes was induced by a single IV injection of $65 \mathrm{mg} / \mathrm{kg}$ body weight of streptozotocin dissolved in $0.01 \mathrm{~mol} / 1$ citrate buffer, $\mathrm{pH} 4.5$. The effectiveness of the treatment was evaluated by estimating glucosuria, polydipsia and polyuria. Blood glucose was determined at the time of sacrifice by the glucose oxidase method. (3) diabetic + insulin: 14 days after streptozotocin administration, diabetic rats were injected daily for 2 weeks with 2 IU protamine-zinc insulin suspension and with corn oil in the same schedule as the preceding groups; (4) diabetic + testosterone: in which 14-day diabetic rats were treated for 2 weeks with a daily SC injection of $500 \mathrm{ug}$ testosterone propionate dissolved in corn oil. Testosterone and insulin administrations were discontinued $24 \mathrm{~h}$ before sacrifice.

The animals (now 90-day old) were sacrificed $(1000 \mathrm{~h}$ throughout) by decapitation, blood was collected and serum was stored at $-20^{\circ} \mathrm{C}$ for testosterone determination. The prostate glands were removed and collected in 3 separate pools for each group.

A separate group of 10 intact control rats was used in the determination of the optimum conditions for binding and saturation studies in prostate cytosol (see below).

\section{Preparation of $105,000 \mathrm{~g}$ Supernatants}

Prostates were minced and homogenized at $0-4^{\circ} \mathrm{C}$ in $1: 8(\mathrm{w} / \mathrm{v})$ ratio with $0.01 \mathrm{~mol} / 1$ Tris- $\mathrm{HCl}$ buffer $\mathrm{pH} 7.4$ containing $1.5 \mathrm{mmol} / \mathrm{l}$ EDTA, $1 \mathrm{mmol} / 1 \mathrm{MgCl}_{2}$ and $0.25 \mathrm{~mol} / \mathrm{l}$ sucrose (buffer $A$ ), using a Polytron $^{\text {B }}$ homogenizer (Kinematica, Steinholfhalde), filtered through Nytex and centrifuged ad $800 \mathrm{~g}$ for $20 \mathrm{~min}$ at $4^{\circ} \mathrm{C}$. The supernatant was further centrifuged at $105,000 \mathrm{~g}$ for $1 \mathrm{~h}$ at $4^{\circ} \mathrm{C}$ in a L2-65 B Beckman ultracentrifuge.

\section{Removal of the Free Endogenous Hormone}

Free endogenous hormone was removed from the cytosol fraction by incubating cytosol with dextran-charcoal (DC-1) buffer: $5 \mathrm{~g} / 1$ dextran T-70 and $50 \mathrm{~g} / 1$ Norit A charcoal in buffer $\mathrm{A}$ in a ratio $10: 1(\mathrm{v} / \mathrm{v})$ at $0-4^{\circ} \mathrm{C}$ for $10 \mathrm{~min}$. The steroid adsorbed to charcoal was precipitated by centrifugation at $3,700 \mathrm{~g}$ at $4^{\circ} \mathrm{C}$ for $20 \mathrm{~min}$. Aliquots of the cytosol were then used for protein estimations. The remaining cytosol was used to assay both unoccupied and total binding sites.

\section{Measurement of Unoccupied Binding Sites}

Following removal of the unbound endogenous hormone, aliquots of the cytosol $(100 \mu \mathrm{l}$ containing approximately $600 \mu \mathrm{g}$ protein) were incubated under conditions of negligible exchange $(16 \mathrm{~h}$ at $\left.0^{\circ} \mathrm{C}\right)$ with ${ }^{3} \mathrm{H}-\mathrm{R} 1881(0.42$ up to $5 \mathrm{nmol} / \mathrm{l})$ in the presence or absence of a 500 -fold excess of radioinert R1881. Separation of free from bound ${ }^{3} \mathrm{H}-\mathrm{R} 1881$ was achieved by adding $50 \mu \mathrm{l}$ of dextran-charcoal $(D C-2)$ buffer: $6.25 \mathrm{~g} / 1$ dextran and $12.5 \mathrm{~g} / 1$ charcoal in buffer $\mathrm{A}$ at $0-4^{\circ} \mathrm{C}$ for $10 \mathrm{~min}$. After centrifugation at $800 \mathrm{~g}$ for $15 \mathrm{~min}$, aliquots of $100 \mu \mathrm{l}$ of the supernatants were taken to measure bound radioactivity. For further experiments the saturating concentration of ${ }^{3} \mathrm{H}-\mathrm{R} 1881(4 \mathrm{nmol} / \mathrm{l})$ was used.

\section{Measurement of the Total Binding Sites by Exchange Assay}

The method of Bonne and Raynaud [13] was employed, with some modifications. In brief, in order to saturate unoccupied binding sites, cytosol stripped of free endogenous hormone was incubated with $10 \mathrm{nmol} / \mathrm{l} \mathrm{DHT}$ at $0-4^{\circ} \mathrm{C}$ for $1 \mathrm{~h}$. The excess $\mathrm{DHT}$ was then removed by adding charcoal buffer (DC-1) to cytosol in a ratio $1: 10(\mathrm{v} / \mathrm{v})$. Following centrifugation at $3,700 \mathrm{~g}$ for $20 \mathrm{~min}$, aliquots of the supernatant were removed for protein estimations. Portions ( $100 \mu \mathrm{l}$ containing approximately $500 \mu \mathrm{g}$ protein) of the saturated cytosol were incubated with ${ }^{3} \mathrm{H}-\mathrm{R} 1881$ ( 4 up to $48 \mathrm{nmol} / \mathrm{l}$ ) at $15^{\circ} \mathrm{C}$ for $16 \mathrm{~h}$. Non-specific binding was determined by parallel incubations with 500 -fold excess of radioinert R1881 for every radiolabelled hormone concentration. Separation of free from bound ${ }^{3} \mathrm{H}-\mathrm{R} 1881$ was achieved by adding $50 \mu \mathrm{l}$ of charcoal buffer (DC-2) at $0-4^{\circ} \mathrm{C}$ for $10 \mathrm{~min}$, and centrifuged at $800 \mathrm{~g}$ for $15 \mathrm{~min}$. Aliquots of the supernatants were taken to measure the bound radioactivity. It was found that the saturation of the total binding sites was achieved at a concentration of $20 \mathrm{nmol} / \mathrm{l}$. For further experiments this saturating concentration was used.

\section{Calculation of Results}

The results were calculated as suggested by Katzenellenbogen et al. [14]. The difference in cpm between cytosols labelled with ${ }^{3} \mathbf{H}-$ R1881 and ${ }^{3}$ H-R1881 + R1881 was taken as a measure of the quantity of DHT receptor. The results are expressed in terms of fmol specifically bound hormone per mg cytoplasmic protein.

\section{Measurement of Specific Binding Protein by Polyacrylamide Gel Electrophoresis}

In a separate set of experiments, three groups of 7 male Wistar, 60-day old rats were used, as follows: control, diabetic, and diabetic + insulin, obtained and handled as described previously (see above), except for corn oil injections. One month later all animals were castrated and sacrificed $48 \mathrm{~h}$ later. Prostates were removed, weighed, pooled and homogenized in cold buffer $B(50 \mathrm{mmol} / 1$ Tris-HCl pH 7.6 containing $1.5 \mathrm{mmol} / 1$ EDTA, $1 \mathrm{mmol} / 1$ ditiothreitol and $0.25 \mathrm{~mol} / 1$ sucrose) in a ratio $1: 3(\mathrm{w} / \mathrm{v})$ using a Polytron $^{\sqrt{3}}$ homogenizer at $0^{\circ} \mathrm{C}$. The homogenates were centrifuged at $105,000 \mathrm{~g}$ for $60 \mathrm{~min}$ at $2^{\circ} \mathrm{C}$. Appropriate aliquots of the supernatants were taken for protein measurements. The cytosol fraction was incubated under constant shaking for $16 \mathrm{~h}$ at $0^{\circ} \mathrm{C}$ with $1 \times$ $10^{-9} \mathrm{~mol} / 1{ }^{3} \mathrm{H}$-DHT. The specific binding protein was characterized by polyacrylamide gel electrophoresis (PAGE) according to Tindall et al. [15], using $3.25 \mathrm{~g} / 100 \mathrm{ml}$ acrylamide, $0.5 \mathrm{~g} / 100 \mathrm{ml}$ agarose and $10 \mathrm{~g} / 100 \mathrm{ml}$ glycerol gels. Samples of $200 \mu \mathrm{l}$ cytosol (containing $1 \mathrm{up}$ to $1.2 \mathrm{mg}$ protein) were layered on the top of the gels and the electrophoresis was run for $3 \mathrm{~h}$ at $2 \mathrm{~mA} /$ tube and approximately $150 \mathrm{~V}$ in $50 \mathrm{mmol} / 1 \mathrm{Tris}, 0.4 \mathrm{~mol} / 1$ glycine buffer pH 8.6 at $0^{\circ} \mathrm{C}$. Following electrophoresis, $2 \mathrm{~mm}$-thick slices of the gels were put directly into counting vials and scintillation mixture was added to determine radioactivity. 


\section{Other Methods}

Radioactivity was measured in a 3320-Packard Scintillation Counter with $50 \%$ efficiency as determined by internal standard.

Protein was measured by the method of Lowry et al. [16].

Endogenous and serum testosterone contents were determined by radioimmunoassay [7], being the lower limit of detection in the standard curve about $10 \mathrm{pg}$ testosterone; the within-assay variance was $8.2 \%$ and the between-assay variance $14.6 \%$.

Total binding sites and $\mathrm{K}_{\mathrm{a}}$ calculations were performed through Scatchard plots of the data [17].

Student's $t$-test was used for statistical analysis.

\section{Results}

\section{Binding of ${ }^{3} \mathrm{H}-\mathrm{R} 1881$ to Rat Prostate Cytosol Receptor under Exchange Conditions}

A typical saturation curve obtained with normal animals for ${ }^{3} \mathrm{H}-\mathrm{R} 1881$ binding to prostate cytosol is shown in Figure 1. Specific binding was saturable at a steroid concentration of approximately $20 \mathrm{nmol} / \mathrm{l}$, after $16 \mathrm{~h}$ incubation at $15^{\circ} \mathrm{C}$. Through Scatchard plots of the data, the association constant $\left(\mathrm{K}_{\mathrm{a}}\right)$ of ${ }^{3} \mathrm{H}$ R1881 to control cytosol binding protein was found to be $0.13 \pm 0.01 \times 10^{9} \mathrm{~mol} / \mathrm{1}^{-1}$. No significant differences were detected in relation to the other groups $\left(\mathrm{D}=0.17 \pm 0.02 \times 10^{9} \mathrm{~mol} / \mathrm{l}^{-1} ; \mathrm{D}+\mathrm{I}=0.10 \pm\right.$ $0.02 \times 10^{9} \mathrm{~mol} / \mathrm{1}^{-1} ; \mathrm{D}+\mathrm{T}=0.12 \pm 0.01 \times$ $10^{9} \mathrm{~mol} / \mathrm{l}^{-1}$ ).

\section{Determination of Free Binding Sites}

In studies with increasing amounts of ${ }^{3} \mathrm{H}-\mathrm{R} 1881$ (Fig. 2), after $16 \mathrm{~h}$ incubation at $0^{\circ} \mathrm{C}$, saturation occurred at low steroid concentration $(4 \mathrm{nmol} / 1)$, indicating a limited number of available binding sites.

\section{Comparison between Normal and Diabetic Rats: Effect of Treatment with Testosterone and Insulin}

The effects of experimentally-induced diabetes and of insulin or testosterone treatment are shown in Table 1 .

Diabetic animals showed reduced body weight gain. The testicular, epidydimal and prostatic weights were diminished in streptozotocin-treated animals, which had overt diabetes, as proved by the marked glucosuria (above $10 \mathrm{~g} / 100 \mathrm{ml}$ ) and elevated serum glucose levels. Serum testosterone and endogenous testosterone contents were lower in diabetic than in control rats.

The mean body weight of the diabetic animals was increased markedly by insulin treatment. Testicular, prostatic, and epididymal weights increased significantly. At the time of sacrifice, many of the

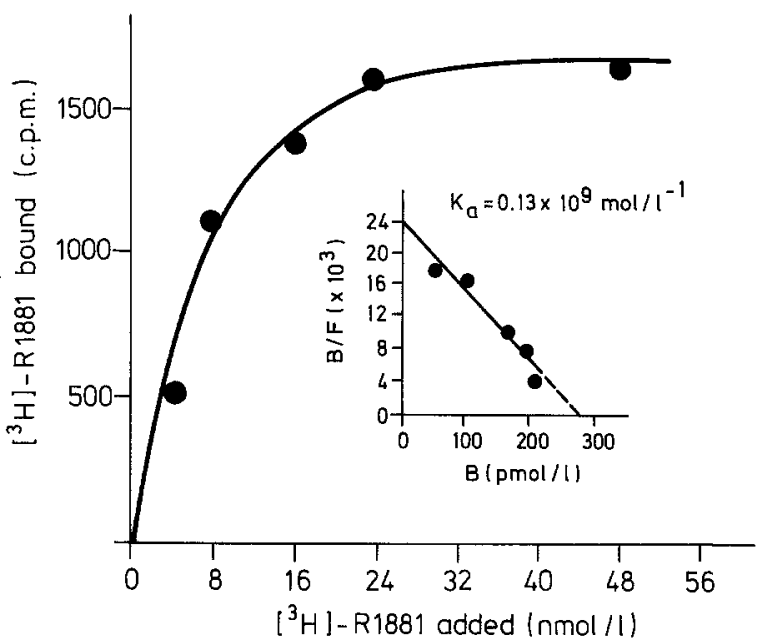

Fig. 1. Saturation curve (exchange assay) of the synthetic androgen ${ }^{3} \mathrm{H}-\mathrm{R} 1881$ specifically bound to control rat prostatic cytosol receptors. Aliquots from a single pool of prostate cytosol from 10 animals were incubated for $16 \mathrm{~h}$ at $15^{\circ} \mathrm{C}$ with increasing concentrations of the androgen in the presence or absence of unlabelled R1881 (500-fold). The curve refers to the specific binding which is calculated by subtracting the non-specific from the total counts (see Materials and Methods). The inset shows the Scatchard plot of specific binding

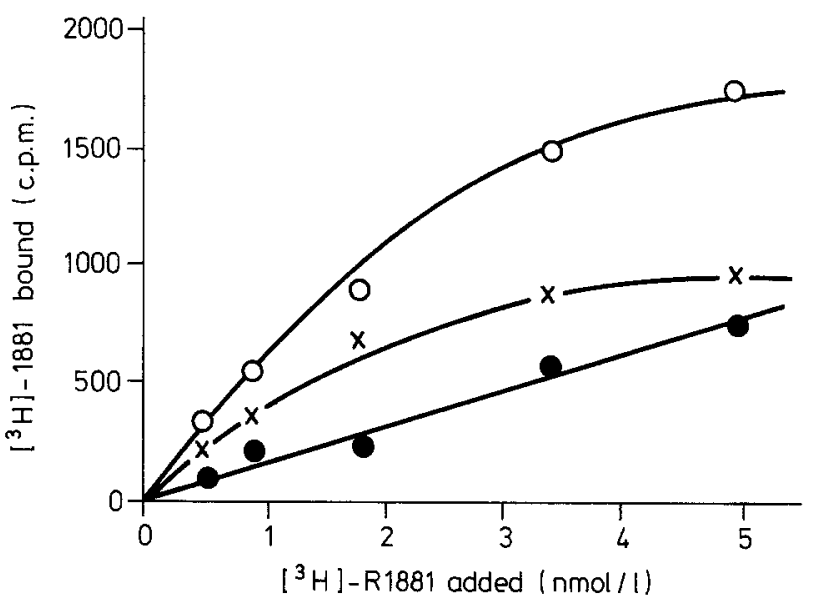

Fig. 2. Saturation curve of ${ }^{3} \mathrm{H}-\mathrm{R} 1881$ to control rat prostatic cytosol receptors. Aliquots from a single pool of prostate cytosol from 10 animals were incubated for $16 \mathrm{~h}$ at $0^{\circ} \mathrm{C}$ with increasing

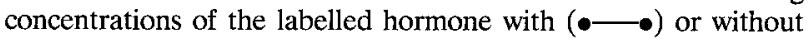
$(\circ-0)$ a 500 -fold excess of radioinert R1881. The specific binding $(\times \stackrel{\times}{-})$ was calculated as in Figure 1

insulin-treated animals were normo- or even hypoglycaemic (Table 1). Both serum levels and endogenous content of testosterone showed conspicuous increases after exogenous insulin, but the serum levels remained lower than the control ones. Testosterone treatment increased prostatic, epididymal, and testicular weights towards normal values. 
Table 1. Effects of streptozotocin diabetes and further insulin and testosterone treatments on several tissue and body parameters of male rats

\begin{tabular}{|c|c|c|c|c|}
\hline \multirow[b]{2}{*}{ Parameter } & \multicolumn{4}{|c|}{ Experimental group } \\
\hline & Control (17) & Diabetic (17) & $\begin{array}{l}\text { Diabetic + } \\
\text { insulin (17) }\end{array}$ & $\begin{array}{l}\text { Diabetic }+ \\
\text { testosterone (10) }\end{array}$ \\
\hline Body weight (g) & $280 \pm 42$ & $171 \pm 37$ & $250 \pm 46$ & $198 \pm 39$ \\
\hline Testicular weight $(\mathrm{g})$ & $1.20 \pm 0.04$ & $0.71 \pm 0.27$ & $1.15 \pm 0.17$ & $0.99 \pm 0.21$ \\
\hline Epididymal weight (g) & $0.40 \pm 0.04$ & $0.18 \pm 0.02^{\mathrm{b}}$ & $0.42 \pm 0.05$ & $0.40 \pm 0.06$ \\
\hline Total prostate weight $(\mathrm{g})$ & $0.24 \pm 0.02$ & $0.15 \pm 0.02^{\mathrm{a}}$ & $0.24 \pm 0.05$ & $0.35 \pm 0.06$ \\
\hline Serum glucose $(\mathrm{mg} / 100 \mathrm{ml})$ & $102 \pm 17$ & $516 \pm 49^{\mathrm{b}}$ & $85 \pm 24$ & $662 \pm 170^{\mathrm{b}}$ \\
\hline Serum testosterone $(\mathrm{ng} / 100 \mathrm{ml})$ & $540 \quad \pm 64$ & $238 \pm 37^{\mathrm{b}}$ & $358 \pm 18^{\mathrm{a}}$ & $1.248 \pm 190^{\mathrm{b}}$ \\
\hline Endogenous testosterone (ng/testis) & $154 \pm 13$ & $41 \pm 5^{b}$ & $142 \pm 9$ & - \\
\hline
\end{tabular}

Results are given as means \pm SEM. Figures in parentheses indicate the number of animals. Statistical comparisons were made in relation to the control values: ${ }^{\mathrm{a}} \mathrm{P}<0.02 ;{ }^{\mathrm{b}} \mathrm{P}<0.001$. Absence of subscript indicates no significant difference

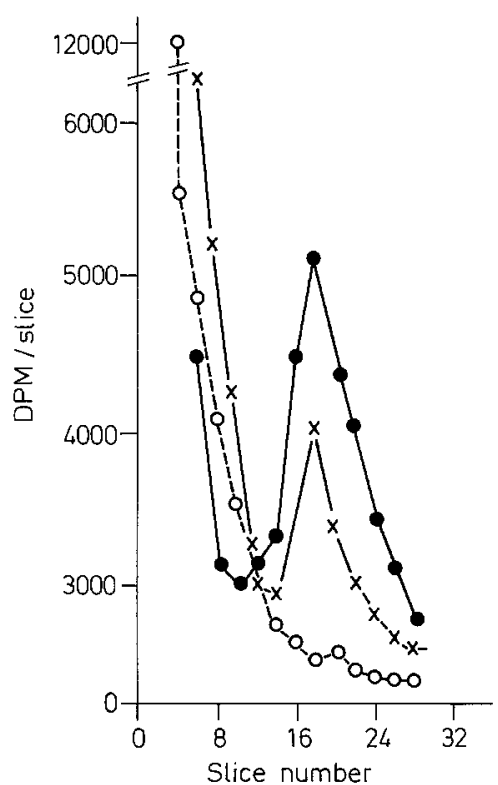

Fig. 3. Polyacrylamide gel electrophoresis (PAGE) of androgenbinding components in prostatic cytosol. Rats were castrated $48 \mathrm{~h}$ before being used. The $105,000 \mathrm{~g}$ supernatants from normal $(\bullet-\bullet)$, streptozotocin-diabetic $(0---O)$ and insulin-treated diabetic rats $(X-X)$ were incubated for $16 \mathrm{~h}$ at $0^{\circ} \mathrm{C}$ with $1 \times$ $10^{-9} \mathrm{~mol} / 1$ of ${ }^{3} \mathrm{H}-\mathrm{DHT}$. Aliquots from every incubation containing 1-1.2 mg protein were then analyzed for binding by PAGE in $3.25 \mathrm{~g} / 100 \mathrm{ml}$ gels containing $0.5 \mathrm{~g} / 100 \mathrm{ml}$ agarose

With respect to the prostate androgen receptors, the results (Table 2) show that the diabetic state significantly decreased androgen-binding capacity, expressed as total or available cytosol binding sites. Exogenous insulin slightly increased the binding capacity, and testosterone treatment of diabetic animals caused a considerable improvement in these parameters.

Similar results were obtained in qualitative studies of cytosol binding protein by PAGE. Figure 3
Table 2. Comparison of cytosol ${ }^{3} \mathrm{H}-\mathrm{R} 1881$ binding sites in prostates from rats after different treatments

\begin{tabular}{lcl}
\hline & \multicolumn{2}{l}{$\begin{array}{l}\text { Cytosol binding sites } \\
\text { (fmol/mg protein) }\end{array}$} \\
\cline { 2 - 3 } Animals & Available & Total \\
\hline Control & $14.8 \pm 1.5^{\mathrm{a}}$ & $94.2 \pm 11.3^{\mathrm{b}}$ \\
Diabetic & $2.8 \pm 1.0$ & $12.6 \pm 3.0$ \\
Diabetic + testosterone & $29.7 \pm 7.7^{\mathrm{a}}$ & $41.1 \pm 3.1^{\mathrm{a}}$ \\
Diabetic + insulin & $8.4 \pm 1.3^{\mathrm{a}}$ & $18.3 \pm 2.4$ \\
\hline
\end{tabular}

Values are means \pm SEM of triplicate determinations. Each group consists of 10 animals, and the prostates were collected in three separate pools for every group. Statistical comparisons were made in relation to the values from diabetic animals: ${ }^{\mathrm{a}} \mathrm{P}<0.05 ;{ }^{\mathrm{b}} \mathrm{P}<$ 0.001 . Absence of subscript indicates no significant difference

shows that, in contrast to normal animals, the prostate cytosol from diabetic rats failed to show a peak of bound radioactivity corresponding to the androgen receptor zone, while this receptor was present in insulin-treated diabetic rats.

\section{Discussion}

The effect of experimentally-induced diabetes on some sexual functions of the male rat have been previously investigated [1-6], and disturbances of hypothalamus-hypophysis-gonadal axis have been reported $[18,19]$. In the present work, the disturbances determined by streptozotocin diabetes were studied after a period of stabilization of the diabetic state, rather than in the very acute insulin depletion. The animals had frank diabetes, as revealed by monitoring serum and urine glucose levels.

Streptozotocin diabetes clearly impaired body weight gain and decreased the weight of the accessory sex glands. Our results show that the administra- 
tion of protamine-zinc insulin and testosterone were able to restore the weight of accessory sex glands (Table 1 ). This has previously been shown in organ culture [10-12].

As shown in Table 2, the diabetic state caused a marked decrease in the prostate soluble androgen receptor, as determined by quantitative methods. The qualitative approach (Fig. 3) indicated a similar decrease in prostate cytosol androgen-binding capacity. This finding is in accordance with the observations of Oksanen and Tuohimaa [9] who reported that streptozotocin diabetes decreased the uptake and retention of ${ }^{3} \mathrm{H}$-testosterone in the prostate and other peripheral, androgen-sensitive target organs.

It is well established that the structure and function of the prostate are dependent on the normal supply of androgens to the organ. The involution of the prostate that follows castration is accompanied by a marked reduction of both the cytoplasmic [20-24] and nuclear $[23,24]$ androgen receptor content. This depletion can be prevented by the administration of androgens $[23,24]$.

The diabetic state produces impaired function of the accessory sex glands, which is partially due to the disturbances in testosterone/dihydrotestosterone metabolism [7, 9]. Howland and Zebrowsky [25] have demonstrated in diabetic male rats a marked reduction in the testosterone serum level. Also, the number of LH-binding sites in Leydig cells from diabetic rats is severely lowered, and can be restored by treatment with insulin [26].

In our conditions, we confirmed that the diabetic state is accompanied by severe reduction of both serum and testicular testosterone. Treatment with exogenous insulin partially restored these to normal (Table 1). Also, a slight increase of the prostate cytosol ${ }^{3} \mathrm{H}-\mathrm{R} 1881$ binding capacity was confirmed (Table 2). This effect was even more prominent in diabetic, testosterone-injected animals.

Oksanen and Tuohimaa [9] suggested that insulin could interact with testosterone in several ways namely, stimulating cell metabolism, facilitating the transport of the androgen into cell cytoplasm or even modifying the action of testosterone at the transcriptional or translational level.

As shown by our results, while testosterone treatment caused a significant increase in androgen binding capacity of prostatic cytosol fraction, insulin alone did not completely restore androgen binding capacity. The small increase observed when insulin was administered could be related to the partial restoration of testosterone secretion, as suggested by data in Table 1.

Notwithstanding, the possibility remains that, at least in part, some of the disturbances observed in diabetic animals could be due to the malnutrition concomitant with disturbed intermediary metabolism. Nevertheless, no differences in Leydig cell binding sites have been reported in food-restricted rats [26].

The present results point to the importance of testosterone and insulin on the maintenance and regulation of testes and accessory sex glands.

Acknowledgements. This work was supported by Grant 39.79.1.76 $\mathrm{R}$ from PLAMIRH. The authors are deeply indebted to Dr. R. Houssay from Upjohn Laboratories and Dr. E. Mendive from Eli Lilly Co. R1881 was generously provided by Dr. J. P. Raynaud, Centre de Recherches, Roussel Uclaf (Romainville, France). Thanks are specially due to Mrs. V. Chiauzzi and Mrs. Ana Rosa de La Camara for skilful technical assistance. R.M.O.-F. is recipient of Fellowship 04-78/0954 from FAPESP.

\section{References}

1. Foglia VG, Borghelli RF, Chieri RA, Fernández Collazo EL, Spindler L, Wesely O (1963) Sexual disturbances in the diabetic rat. Diabetes $12: 231-237$

2. Schöffling K, Federlin K, Ditschuneit H, Pfeiffer EF (1963) Disorders of sexual function in male diabetics. Diabetes $12: 519-527$

3. Schöffling K, Federlin K, Schmitt W, Pfeiffer EF (1967) Histometric investigations on the testicular tissue of rats with alloxan diabetes and Chinese hamsters with spontaneous diabetes. Acta Endocrinol (Kbh) 54:335-346

4. Foglia VG (1945) El peso de los órganos de la rata diabética. Rev Soc Argent Biol 21:45-53

5. Foglia VG, Rosner JM, Cattaneo de Peralta Ramos M, Lema BE (1969) Sexual disturbances in the male diabetic rat. Horm Metab Res 1:72-77

6. Cattaneo de Peralta Ramos M, Irusta O, Foglia VG (1973) Acción de las gonadotrofinas e insulina sobre la producción de testosterona por testículos de ratas diabéticas. Rev Soc Argent Biol 49:56-60

7. Tesone M, Valle LBS, Foglia VG, Charreau EH (1976) Endocrine function of the testis in streptozotocin diabetic rats. Acta Physiol Lat 26:387-394

8. Angervall L, Hesselsjo R, Nilsson S, Tisell LE (1967) Action of testosterone on ventral prostate, dorsolateral prostate, coagulating glands and seminal vesicles of castrated alloxandiabetic rats. Diabetologia 3:395-401

9. Oksanen A, Tuohimaa P (1975) Testicular lesions of streptozotocin diabetic rats. Horm Res $6: 138-144$

10. Calame SS, Lostroh AJ (1964) Effect of insulin and lack of effect of testosterone on the protein of ventral prostates from castrated mice maintained as organ cultures. Endocrinology $75: 451-454$

11. Lostroh AJ (1971) Effect of testosterone and insulin in vitro on maintenance and repair of the secretory epithelium of the mouse prostate. Endocrinology $88: 500-503$

12. Sufrin G, Prutkin L (1974) Experimental diabetes and the response of the sex accessory organs of the castrated male rat to testosterone propionate. Biochemical and electron microscopic observations. Invest Urol 11:361-369

13. Bonne C, Raynaud JP (1976) Assay of androgen binding sites by exchange with methyltrienolone (R1881). Steroids 27 : 497-507

14. Katzenellenbogen JA, Johnson HS, Carlson KE (1973) Studies on the uterine cytoplasmic estrogen binding protein. Thermal stability and ligand dissociation rate. An assay of 
empty and filled sites by exchange. Biochemistry 12: 4092-4099

15. Tindall DJ, Hansson V, McLean WS, Ritzen EM, Nayfeh SN, French FS (1975) Androgen-binding proteins in rat epididymis: properties of a cytoplasmic receptor for androgen similar to the androgen receptor in ventral prostate and different from androgen-binding protein (ABP). Mol Cell Endocrinol 3: 83-101

16. Lowry OH, Rosebrough NJ, Farr AL, Randall RJ (1951) Protein measurement with the folin phenol reagent. J Biol Chem $193: 265-275$

17. Scatchard G (1949) The attraction of proteins for small molecules and ions. Ann N Y Acad Sci 51:660-672

18. Hunt EL, Bailey DW (1961) The effects of alloxan diabetes on the reproductive system of young male rats. Acta Endocrinol (Kbh) 38:432-440

19. Howland BE, Zebrowski EJ (1974) Serum and pituitary gonadotropin levels in alloxan-diabetic rats. Horm Metab Res 6:121-124

20. Jung L, Baulieu EE (1971) Neo-nuclear androgen receptor in rat ventral prostate. Biochimie 53:807-817

21. Mainwaring WIP, Mangan FR (1973) A study of the androgen receptors in a variety of androgen-sensitive tissues. J Endocrinol 59:121-139
22. Sullivan JN, Strott CA (1973) Evidence for an androgen-independent mechanism regulating the levels of receptor in target tissue. J Biol Chem 248:3202-3208

23. Bruchovsky N, Cravan S (1974) Prostatic involution: effect on androgen receptors and intracellular androgen transport. Biochem Biophys Res Commun 62:837-843

24. Blondeau JP, Corpéchot C, Goascogne C, Baulieu EE, Robel $P$ (1975) Androgen receptors in the rat ventral prostate and their hormonal control. Vitam Horm 33:319-345

25. Howland BE, Zebrowsky EJ (1976) Some effects of experimentally-induced diabetes on pituitary-testicular relationships in rats. Horm Metab Res 8:465-469

26. Charreau EH, Calvo JC, Tesone M, Valle LBS, Barañao JL (1978) Insulin regulation of Leydig cell luteinizing hormone receptors. J Biol Chem 253:2504-2506

Received: May 21, 1979,

and in revised form: November 9, 1979

Dr. Marta Tesone

Instituto de Biología y Medicina Experimental

Obligado, 2490

(1428) Buenos Aires

Republica Argentina 